\title{
The Effect of Tri Hita Karana Local Wisdom on Financial Performance of UP3HP Jempiring Group in Regency Badung
}

\author{
Ni Wayan Surya Suryathi ${ }^{1}$, Made Antara ${ }^{2}$, Nengah Bawa Atmaja ${ }^{3}$, Wayan Windia ${ }^{4}$ \\ ${ }^{1}$ Undiknas University, Denpasar-Bali, Indonesia. \\ ${ }^{2,4}$ Postgraduate Agricultural Science Program, Udayana University, Denpasar-Bali, Indonesia \\ ${ }^{3}$ Ganesha University, Singaraja-Bali, Indonesia
}

\begin{abstract}
Every business group that is in the community, if run in earnest, tenacious, enterprising, and honest matters, will usually succeed in achieving its goals. The Jempiring Group of Service Unit, Development and Processing of Agricultural Products (UP3HP) in Badung regency obtain capital assistance from the Government and required to be accountable to the government as a form of success/group's performance in running its business. The purpose of this study is to determine the influence of local wisdom Tri Hita Karana on financial performance UP3HP Jempiring Group in Badung regency. The result and discussion show that local wisdom Tri Hita Karana have a strong influence on Financial Performance of UP3HP Jempiring Group in Badung regency. This is because Tri Hita Karana has penetrated each member of the UP3HP Jempiring group in the implementation of the community both in religious ceremonies, such as the ceremony of Dewa Yadnya, Manusa Yadnya, Pitra Yadnya or Butha Yadnya, menyamebraya activity, as well as its existence in preserving plants related with the processing of agricultural produce.
\end{abstract}

Keywords: financial performance, local wisdom.

Author Correspondence:

Ni Wayan Surya Suryathi

Undiknas University, Denpasar, Bali, Indonesia

E-mail: suryathiniwayan@yahoo.com

\section{Introduction}

\subsection{Background of Study}

Local wisdom Tri Hita Karana is a Balinese Hindu philosophy that is believed to provide guidance in maintaining harmonious relationships in the life of the community. As well, with the life of business groups founded by PKK's women in the village of Blahkiuh, Abiansemal, Badung regency, the group UP3HP Jempiring. In maintaining the continuity of their group's business, they always prioritize the local wisdom of Tri Hita Karana through their belief in maintaining the harmonious relationship with Ida Sang Hyang Widhi Wasa (Parahyangan), maintaining the harmonious relationship with fellow human beings (Pawongan), and maintaining the harmonious relationship with nature (Palemahan).

Today, the UP3HP Jempiring group Blahkiuh, Abiansemal, Badung regency is still running well, because they have a strong desire and commitment to keep the business going, persistent in running their business, honest in doing business, responsible, communicating with each member of the group every month, and active in reporting aid funds provided by the Government of Badung regency for processing agricultural products, $\mathrm{Rp} 25,000,000.00$ in total.

The success of UP3HP Jempiring group in improving its performance is not only caused by a capital factor, technological factors, availability of production facilities, and farmer involvement in farmer 
groups [1], human resources factors [2], organizational culture, communication, product quality [3]. But also, according to interview results, [4] that the success of an organization is due to the cultural capital of local wisdom Tri Hita Karana as the three causes of happiness [5]. This is reinforced by various studies and facts that show a developed nation is a nation that has a strong character. The values of these characters are the values of local wisdom excavated from the cultural treasures that are in harmony with the characteristics of the local community. Japan became a developed nation thanks to its success in internalizing the spirit of bushido excavated from the spirit of their ancestors (the samurai). South Korea became a respected nation in Asia, even in the world thanks to the success of digging the noble values that are reflected in the spirit of semaul undong. China with the spirit of Confucianism, and Germany with its ethics protestant.

Understanding Religion from a sociological perspective is essentially a way of looking at religion by focusing on humanity (especially social aspect) in religious belief systems and practices [6]. The sociology of religion is often defined as the study of the interrelationship between religion and society, as well as the forms of social interaction that occur as a result of the dialectic that occurs between religion on the one hand and society on the other [6]. Local wisdom applied by UP3HP Jempiring Group Blahkiuh, Abiansemal, Badung regency is not of the same quality, because local wisdom is a recipe for action. One group / one person can execute it consistently, but others may not be able to. Those factors make it interesting to examine the influence of Local Wisdom Tri Hita Karana on Financial Performance of UP3HP Jempiring Group in Badung regency. The problem studied in this research is, how the influence of Local Wisdom Tri Hita Karana affects the Financial Performance of UP3HP Jempiring Group in Badung regency? With the aim to analyze and reveal the influence of local wisdom Tri Hita Karana on the financial performance of UP3HP Jempiring Group in Badung regency.

\subsection{Literature Review}

\section{Local Wisdom Theory}

Local wisdom is a conceptual idea that lives in society, grows and develops continuously in the awareness of society that can be approached from religious values, ethical, aesthetic, intellectual or even other values such as economics, technology etc. [7]. Local wisdom can be interpreted as a thought of life based on a clear reason, a good mind, and contains positive things and can be translated as the work of reason, deep feelings, nature, form of temperament, and the suggestion for human glory [8].

The value of local wisdom will have a meaning if it remains a reference in overcoming every dynamic of social life. The existence of the value of local wisdom will be tested in the midst of a dynamic social life. Empirically, the value of local wisdom that grows and develops in Balinese society has been tested its efficacy, at least when the reform process takes place, multi-party elections and social conflicts nuanced between youth, economic and political issues can be muffled [9]. The Balinese society as a unity of geography, ethnicity, race, religion has the value of local wisdom that has been tested and proved its social roaming in overcoming various problems of social life. The value of local wisdom that developed and believed as a social glue that often becomes a reference in managing relationships and harmony among fellow religious communities in Bali Province, including the value of local wisdom Tri Hita Karana [9]. The philosophy of Tri Hita Karana teaches about the balance of the reciprocal relationship between man and God, the man with man, and the man with nature or his environment. The three elements of Tri Hita Karana namely, Parahyangan is covering the values or spiritual layer, Pawongan that includes the sociocultural layer, and Palemahan is covering the natural-physical 
environment [10].

\section{Financial Performance Theory}

The financial statements are financial information that describes the financial performance of a company [11]. Company's financial performance is shown from the financial statements in generating revenue with resources owned by the company [12]. Financial performance is a tool to assess the performance and financial condition of a company, using a ratio size or index showing the relationship between two / more financial data [13]. Performance appraisal can be utilized by management for 1) Manage organizational operations effectively and efficiently through maximum employee motivation; 2) Helping the decision-making concerned with its employees such as promotion, dismissal, mutation; 3 ) Identify training and employee development needs and to provide criteria for selection and evaluation of employee training programs; 4) Provide feedback to employees on how their employers assess their performance; 5) Provides a basis for award distribution [14].

Information about the financial performance of a company will be very useful in the decisionmaking process, both for internal and external parties of the companies. Internal parties of the company, especially the management company to use as a tool for performance evaluation in the past and as a guide in preparing the company's work plan in the future. For external parties, especially investors, the measurement of the company's financial performance can be used as the basis for making investment decisions [15]. The financial performance of a company is very useful for various parties (stakeholders) such as investors, creditors, analysts, financial consultants, brokers, government, and the management itself [16].

Financial ratio is a tool that can be used to assess the performance of management within a period, whether it reaches the target as it has been set, assess the ability of management in empowering the company's resources effectively, can be used as an evaluation material, to know the policies that must be taken by the owners of the company to make changes to the people who sit in the future management [17]. Some common financial ratios applied to evaluate the company's financial performance include liquidity ratio, solvency ratio, activity ratio, profitability ratio, and operating ratio, [18].

\section{Social Construction Theory}

The theory of social constructivism is rooted in a constructivist paradigm that sees social reality as a social construction created by an individual who is a free man. However, the truth of a social reality is relative, which applies to the specific context considered relevant by the social actors. The theory of social construction is the theoretical building of Berger and Luckmann. Berger is a sociologist from New School for Social Research, New York. While Luckmann is a sociologist from the University of Frankfurt. Social construction theory of Berger and Luckmann is a contemporary sociology theory based on the sociology of knowledge [19].

In social construction theory, there is understanding that reality is built socially, as well as reality and knowledge are the two key terms to understand it. Reality is a quality contained in phenomena that are acknowledged to have their own being so they are independent of human will; whereas knowledge is the assurance that phenomena are real and have specific characteristics [20]. In the philosophy, the idea of constructivism has emerged since Socrates discovered the soul in the human body since Plato discovered reason and ideas. The idea became even more concrete after Aristotle introduced terms, information, relationships, individuals, substance, material, essence, etc.. Aristotle states that, man is a 
social being, every statement must be verified, that the key to knowledge is fact [21].

If social theories do not perceive importance or ignore the interplay or dialectic between these three moments, then they can cause a theoretical stagnancy. Dialectics runs simultaneously, meaning there is a process of pulling out (externalization) so as it is outside (objective) and then there is a process of recall into (internalization) so that something that is outside it as if it is in self or subjective reality [22]. Whereas objectivation is the process of self-manifestation (the disclosure of subjective reality) into the forms of activity available and can be known by others as elements of the world together. An example of objectivation is when angry someone pulls out a weapon. The act of pulling a weapon out is interpreted by others as an objective fact that the person is angry. While internalization is a direct understanding or interpretation of an objective event as the disclosure of a meaning. Or to understand the subjective processes of others become meaningful to us [23].

Berger states that the reality of everyday life has subjective and objective dimensions. Humans are instrumental in creating objective social reality through the process of externalization, as humans influence it through the process of internalization (which reflects subjective reality). Society is a product of human and human is the product of society. Both humans and society are dialectics between the two. Society has never been the final product, but still as a process that is being formed [24]. A process of meaning done by every individual to the environment outside itself consists of the process of externalization, internalization, and objectivation. Externalization is an adjustment to the sociocultural world as a human product, objectivation is the social interaction in the intersubjective world institutionalized or institutionalized process, and the internalization is the individual identifies amidst the social institutions in which the individual becomes a member [25].

\section{Material and Methods}

In this research, the data collection procedure are as follows: 1) Observation of participation; 2) Deep interview; 3) Focus Group Discussion [26] (FGD). Data analysis used is qualitative data analysis as a research procedure that produces descriptive data in the form of written or oral words from people or behavior that can be observed [27]. The descriptive-qualitative research approach is a research that is not focused on hypothesis testing but aims to describe the social reality by constructing the reality that occurred in the community that has links with the UP3HP Jempiring group Badung.

The sociological approach of phenomena in religious societies can be understood empirically to achieve general social law. Using a sociological approach means understanding religion not only as a theologically-dogmatic teaching, but seeing the religious practice existing within the religious community itself, both presented from their institutions and their daily practices. The use of sociological approach, the construction process of understanding of teaching according to UP3HP Jempiring group of Badung regency can be understood by looking at social interaction among members. Furthermore, the form of values and norms that become collective identity becomes a social fact that becomes one of the signs as a religious society [28].

\section{Results and Discussion}

\subsection{Research Results}

The financial performance of UP3HP Jempiring Group in Badung regency can be shown from the resultant financial report, which consists of Financial Position Report (FPR) and Comprehensive Income. Comparison of financial statements is presented in Table 1 and 2 below. 
The Effect of Tri Hita Karana Local Wisdom on Financial Performance of UP3HP Jempiring Group in Regency Badung

Table 1

Comparison of Financial Position Report UP3HP Jempiring Group, Badung regency

Per January 1st to June 30th, 2015

\begin{tabular}{ccccccc}
\hline ASSETS & January & February & March & April & May & June \\
\hline Cash & $6,550,000.00$ & $1,975,000.00$ & $8,715,500.00$ & $1,292,500.00$ & $1,511,500.00$ & $1,760,000.00$ \\
Credit & $34, .578,850.00$ & $45,518,200.00$ & $56,513,000.00$ & $49,626,000.00$ & $41,340,500.00$ & $53,124,500.00$ \\
Stock & $11,550,500.00$ & $10,600,300.00$ & $5,425,000.00$ & $5,975,000.00$ & $6,887,000.00$ & $8,345,000.00$ \\
Equipment & $9,980,000.00$ & $7,725,000.00$ & $11,150,000.00$ & $7,855,000.00$ & $10,275,000.00$ & $9,610,000.00$ \\
\hline Total & $66,659,350.00$ & $63,818,500.00$ & $81,803,500.00$ & $64,748,500.00$ & $60,014,500.00$ & $72,839,500.00$ \\
\hline LIABILITIES & January & February & March & April & May & June \\
Debt & $5,400,000.00$ & $6,750,000.00$ & $2,625,000.00$ & $4,125,000.00$ & $4,875,000.00$ & $7,500,000.00$ \\
Profit running & $38,259,350.00$ & $40,068,500.00$ & $60,178,500.00$ & $41,623,500.00$ & $36,139,500.00$ & $46,339,500.00$ \\
month & $19,000,000.00$ & $19,000,000.00$ & $19,000,000.00$ & $19,000,000.00$ & $19,000,000.00$ & $19,000,000.00$ \\
Initial capital & $66,659,350.00$ & $63,818,500.00$ & $81,803,500.00$ & $64,748,500.00$ & $60,014,500.00$ & $72,839,500.00$ \\
\hline Total & & & & &
\end{tabular}

Source: Laporan Posisi Keuangan Kelompok UP3HP Jempiring Badung regency [29].

The result of calculation of financial position report (FPR) from January to June 2015 shows that the position of assets owned by UP3HP Jempiring Group of Badung regency tends to fluctuate. In March 2015, the position of assets increased, because in March 2015 coincided with the Nyepi holiday, this indicates that in Bali the marketing of jajan begina will increase in the time before religious festivals. Likewise, in May to June 2015, the value of assets increased, because ahead of the Galungan holiday in July 2015 which in this study was not investigated.

The liabilities position consisting of Debt and Capital from January to June 2015 also fluctuates. Increased liabilities in March, May, and June 2015 due to additional earnings obtained by the UP3HP Jempiring Group of Badung regency during Nyepi and ahead of the Galungan holiday in July 2016. Based on the result of comparison of comprehensive income of UP3HP Jempiring Group of Badung regency from January to June 2015 in Table 2, the result tends to fluctuate. Profits derived from January to March 2015 continue to increase at Rp 38,259,350.00 in January 2015, in February amounting to Rp 40,068,500.00, March 2015 at the Nyepi festival of Rp 60,178,500.00.

In April of 2015, the profit earned decreased to Rp 41,623,500.00. Bulan May 2015 drops to Rp 36,139,500.00. June 2015 rose to Rp 46,339,500.00. Increase in earnings in June 2015, due to the July 2015 Galungan holiday, not investigated in this study. In the comprehensive income statement already includes the costs associated with the implementation of Tri Hita Karana, which is the cost for the purchase of canang and "banten" that are required for every religious ceremony, the expenses incurred for the menyamebraya activities related to the implementation of Panca Yadnya, as well as the cost for the maintenance and purchase of bird and dog foods

The influence of local wisdom Tri Hita Karana (THK) as the three causes of happiness, which has the following elements: 1) the existence of harmony between man and God Almighty (Parahyangan); 2) between man and his fellow human beings (Pawongan); 3) between man and his natural environment (Palemahan) on financial performance is described as follows. 
The Effect of Tri Hita Karana Local Wisdom on Financial Performance of UP3HP Jempiring Group in Regency Badung

Table 2

Comprehensive Profit and Loss Income UP3HP Jempiring Group, Badung regency

January to June 2015

\begin{tabular}{|c|c|c|c|c|c|c|}
\hline & January & February & March & April & May & June \\
\hline $\begin{array}{l}\text { Sales results } \\
\text { Cost of } \\
\text { goods sold: }\end{array}$ & $188,343,850,00$ & $169,333,000.00$ & $250,099,000.00$ & $174,461,000.00$ & $179,611,000,00$ & $218,479,000.00$ \\
\hline Sticky rice & $56,250,000.00$ & $42,750,000.00$ & $67,500,000.00$ & $49,500,000.00$ & $57,150,000.00$ & $78,300,000.00$ \\
\hline Wheat flour & $12,000,000.00$ & $11,360,00000$ & $24,000,000.00$ & $11,600,000.00$ & $12,000,000.00$ & $13,600,000.00$ \\
\hline Sugar & $11,400,000.00$ & $11,076,000.00$ & $17,280,000.00$ & $10,424,000.00$ & $11,580,000.00$ & $11,976,000.00$ \\
\hline $\begin{array}{c}\text { Javanese } \\
\text { sugar }\end{array}$ & $9,600,000.00$ & $9,065,000.00$ & $12,000,000.00$ & $9,925,000.00$ & $9,725,000.00$ & $10,400,000.00$ \\
\hline Coconut & $246,000.00$ & $225,000.00$ & $350,000.00$ & $210,000.00$ & $246,000.00$ & $265,000.00$ \\
\hline Salt & $120,000.00$ & $100,000.00$ & $150,000.00$ & $120,000.00$ & $120,000.00$ & $135,000.00$ \\
\hline Vegetables & $2,700,000.00$ & $2,100,000.00$ & $3,500,000.00$ & $1,500,000.00$ & $2,250,000.00$ & $2,150,000.00$ \\
\hline Blueband & $3,600,000.00$ & $3,115,000.00$ & $5,200,000.00$ & $3,200,000.00$ & $2,975,000.00$ & $2,995,000.00$ \\
\hline Eggs & $8,400,000.00$ & $7,830,000.00$ & $12,000,000.00$ & $8,340,000.00$ & $8,067,000.00$ & $8,316,000.00$ \\
\hline Oil & $18,000,000.00$ & $16,500,000.00$ & $19,600,000.00$ & $11,430,000.00$ & $12,200,000.00$ & $16,772,000.00$ \\
\hline $\begin{array}{l}\text { Direct } \\
\text { Wages }\end{array}$ & $13,500,000.00$ & $13,500,000.00$ & $13,500,000.00$ & $13,500,000.00$ & $13,500,000.00$ & $13,500,000.00$ \\
\hline $\begin{array}{l}\text { Total Cost } \\
\text { of Goods }\end{array}$ & $135,816,000.00$ & $117,621,000.00$ & $175,080,000.00$ & $119,749,000.00$ & $129,813,000.00$ & $158,409,000.00$ \\
\hline $\begin{array}{l}\text { Gross profit } \\
\text { Operating } \\
\text { costs: }\end{array}$ & $52,527,850.00$ & $51,712,000.00$ & $75,019,000.00$ & $54,712,000.00$ & $49,798,000.00$ & $60,070,000,00$ \\
\hline $\begin{array}{l}\text { Firewood } \\
\text { and gas }\end{array}$ & $5,700,000.00$ & $5,130,000.00$ & $7,330,000.00$ & $5,500,000.00$ & $6,100,000.00$ & $4,995,000.00$ \\
\hline $\begin{array}{l}\text { Electric } \\
\text { pulse }\end{array}$ & $360,000.00$ & $365,000.00$ & $520,000.00$ & $360,000.00$ & $475,000.00$ & $450,000.00$ \\
\hline Gasoline & $126,000.00$ & $126,000.00$ & $126,000.00$ & $126,000.00$ & $126,000.00$ & $126,000.00$ \\
\hline Boc & $525,000.00$ & $475,000.00$ & $512,000.00$ & $420,000.00$ & $493,000.00$ & $487,000.00$ \\
\hline Plastic & $300,000.00$ & $250,000.00$ & $325,000.00$ & $250,000.00$ & $382,000.00$ & $295,000.00$ \\
\hline $\begin{array}{c}\text { Pulsa HP } \\
\text { Canang, } \\
\text { menyamebra }\end{array}$ & $180,000.00$ & $180,000.00$ & $180,000.00$ & $180,000.00$ & 180,00000 & $180,000.00$ \\
\hline $\begin{array}{c}y a, \\
\text { dogfood.bird } \\
\text { food }\end{array}$ & $6,965,000.00$ & $5,005,000.00$ & $5,735,000.00$ & $6,140,000.00$ & $5,790,000.00$ & $7,085,000.00$ \\
\hline $\begin{array}{l}\text { Lease loss } \\
\text { Total }\end{array}$ & $112,500.00$ & $112,500.00$ & $112,500.00$ & $112,500.00$ & $112,500.00$ & $112,500.00$ \\
\hline $\begin{array}{c}\text { Operational } \\
\text { Cost }\end{array}$ & $14,268,500.00$ & $11,643,500.00$ & $14,840,500.00$ & $13,088,500.00$ & $13,658,500.00$ & $13,730,500.00$ \\
\hline $\begin{array}{c}\text { Profit and } \\
\text { loss }\end{array}$ & $38,259,350.00$ & $40,068,500.00$ & $60,178,500.00$ & $41,623,500.00$ & $36,139,500.00$ & $46,339,500.00$ \\
\hline
\end{tabular}

Source: Laba Rugi Komprehensif Kelompok UP3HP Jempiring Badung regency [29].

\section{The harmonious relationship between man and God Almighty (Parahyangan).}

Parahyangan is one dimension of THK philosophy which emphasizes that welfare is achieved when realized the harmonious relationship between man and God the creator. The harmonious relationship of Hindu community in Bali to God (Ida Sang Hyang Widi Wasa) is implemented by presenting yadnya. Yadnya that is implemented definitely requires supporting facilities such as artha. To be able to obtain artha the Hindu community in Bali do it by working in order to meet the needs of his life including the need for ritual (religious ceremony). Because according to [30] that a person will not achieve happiness by silence or without work. A person will not achieve perfection, and or freedom by avoiding work.

The concept of artha (in catur purusa artha) and panca yadnya ultimately encourage the Hindu 
community in Bali to work hard in order to obtain income in meeting all needs, including ritual needs in the form of yadnya. However, in the implementation, the concept of artha cannot be separated and must be guided by the concept of dharma, karma, and moksa which in its application is still often interchangeable [31]. In Sloka Bhagavadgita IV.12 it is stated that one who wishes a success from his work activity, he must do yadnya (sacrifice) to God in this world because work activity will be realized if accompanied by yadnya or sacrifice both in material form as well as in spiritual form. Sacred sacrifice in the form of matter can be in the form of Banten (canang) while sacred sacrifice in spiritual form can be in the form of prayer or meditation. The sloka above gives clues that people who want to live successfully in this world must be persistently "work and pray".

The essence of Balinese Hindu ritual is a symbol of the hearts of Hindu hearts to God who wants to reward all the contents of the universe to God. The idea of Balinese Hindu ritual, as stated in Yadnya Prakerti's lontar: shining bebanten pinaka Anda Bhuvana. "All means of ritual or"banten are the symbols of the universe, which are inflicted with Banten Sarad, which has three symbolic meanings: 1) as a symbol of a vertically harmonious relationship between man and God, 2) as a symbol of horizontal harmonious relationship between fellow human beings, 3) as a symbol of horizontal harmonious relationship between man and nature. Therefore, Banten sarad is the symbol of the universe (macro cosmos) and everything that exists in the universe (Anda Bhuwana) [32]. The ritual in the form of Banten is a spiritual science related to methodology and soul technology that allows the soul to recognize itself and return to its true identity. Thus, the ritual in the form of a very functional Banten leads the human soul to rediscover its original consciousness. This is also the reason why the knowledge of the soul (Atma) in the science of yoga is called the king of science (rajavidya) [32].

UP3HP Jempiring group Badung as part of Hindu society in Abiansemal Badung, in an effort to achieve their family welfare by doing work in groups. In connection with business activities, it must be realized that the human activity of the business is an offering to God Almighty. Business activity is an offering that does not escape the control of God [33]. The UP3HP Jempiring Group of Badung regency strongly believes that the profits will be obtained if always remember to offer yadnya offerings that are implemented through Banten. Of these benefits are expected to improve the welfare of family members (family jagadita). Implementation of yadnya implemented reinforced by the holy book Bhagawadgita III: 10 reads as follows.

\section{Sahayajnah prajah sriahtva}

Para vachaa prajapatih

Anena prasa vishya dhivam

Esha yo'stvishta kamadhuk.

Meaning:

Indeed from the very beginning, Prajapati created man with yadnya and said: with this, you will grow and will be kamadhuk of your wishes [34]. Based on the quotation Sloka III.10 Bhagawadgita it can be understood that yadnya can be understood philosophically that reminds everyone in the process of life to always do work with the spirit of offerings (yadnya) in accordance with attitude and behavior, God created nature and its contents and including man [30].

Associated with the existence of UP3HP Jempiring Group Badung regency in the use of Community 
Direct aid (BLM) funds from Government of Badung regency. BLM provided by the Government is realized in the form of savings and loans and reported every six months by the head of the UP3HP Jempiring Group Badung. In relation to the report submitted by the chairman of the Group, the report is made in accordance with the transactions that occurred for six months. Reports are made with what they are (not reporting falsehoods and cheats) because the group is very confident that God will control all activities carried out. Similarly, the behavior of all members of the group, at the time of returning installment of savings and loans. Group members are always honest, obedient, and loyal in returning the debts borrowed from the group. Because members of the group feel confident that if doing a lot of cheating, then God will definitely control his actions, and usually will encounter obstacles in every activity.

Relation to offerings in the kitchen (yadnya sesa), and in place of pelinggih Ida Ratu Rambut Sedana every day is a form of gratitude to God. Likewise, with the presence of members of groups who sell in the market, every day also give offerings (Banten) in pelangkiran. Offerings (Banten) is as a form of implementation of Tri Hita Karana is executed consciously, sincerely sincere, unconditional.

The relationship between business activities with God Almighty (Ida Sang Hyang Widhi Wasa) is also seen through the presence of temples in the area of business activities. Temple is used by the employees, by people who have a business as a mediator of its relationship with God Almighty [33]. Harmonious relationship with God Almighty is also seen with the presence of Melanting Temple that is in the Market where the members of the group doing sales activities of agricultural products.

\section{The harmonious relationship between man and his fellow human beings (Pawongan)}

Pawongan comes from the word Wong (people or residents). Pawongan is a matter related to people in one community life, in a narrow sense pawongan is a group of human society who live in one region. Pawongan is a concept that wants a harmony between human beings with each other. In business activities, it must be realized that the business is essentially a human figure as a creature of God. As a creature of God, the businessman is no different from other fellow creatures, who may be workers or employees. Therefore, the business must maintain harmony with each other internally and externally, in order to avoid conflicts with the surrounding community environment. Conflict will cause business activities to discontinue [33]. THK philosophy implementation is through harmonious relationship among human beings. In the business context, the relationship is between employees and the relationship of institutions with the community. Relationships with fellow human beings and other creatures are the relationship between family members, society, between children, husband and wife and others. This human relationship should be able to create an atmosphere of peace, harmony, and peace and help each other with a heart filled with love.

In manu smerti II,138 stated:

"Satyam bruyat priyam bruyam

na bruyam Satyam, priyam canartam,

bruyat esa dharmah sanatanah"

The mean:

Talk naturally do not say harsh words. Though the words are true, do not say gentle words but lies. 
This is the eternal law of eternity (Sanatana Dharma). Good behavior is the absolute base in life as a human being because by doing humans can improve their lives both sekala and Niskala.

Implementation of harmonious relationships with fellow human beings not only occur in life in society, but there are also implemented in the form of offerings (religious rituals) including the following.

Manusa Yadnya, the sacred offering of a sincere sacrament to man.

In the formulation of Vedic Scriptures and Books of Hindu Literature, Manusa Yadnya or Nara Yadnya is to feed the community (maweh apangan ring kraman) and serve guests in a ceremony (athiti puja). However, in its application in Bali, Yadnya Manusa ceremony classified Sarira Samskara. The essence of Sarira Samskara is the improvement of human quality. Manusa Yadnya in Bali is done since the baby is still in the womb, until Pawiwahan or marriage ceremony.

Implementation of Manusa Yadnya activity which was followed by members of UP3HP Jempiring group of Badung regency during January to June 2015 were tooth cutting activities (metatah), otonan activities, and marriage ceremony activities (pawiwahan). This activity is followed by all members of the group, not an obligation, but because of kinship, and kinship relationships and are in a Banjar adat, the group members as members of the Banjar must attend the ceremonies.

Rsi Yadnya, which is a sacred sacrament ceremony sincere to the saints of the Hindus.

In the practice of ceremony in Bali, which is classified Rsi Yadnya ceremony is Rsi Bojana ceremony that is a tribute ceremony at Sulinggih or Pendeta in the form of serving the food served honorably. Serving the Daily Pastor as well as the times he leads the ceremony, deepens the literary books let alone the Vedic scriptures is to continue the ideals of all Rsi, all of these are called Rsi Yadnya.

The concept of pawongan is also limited by the territory and authority obtained by the community within certain boundaries. Pawongan to the regional level includes Hindus in Bali. For indigenous villages include karma traditional village. The family level includes all family members. This can be seen clearly with the existence of the tradition of ngoopin (helping others sincerely) in the Hindu community in Bali. The relationship between human beings with other creatures is the relationship between family members, society, between children, husband and wife and others [35].

Besides the activities of Manusa Yadnya and Rsi Yadnya, the implementation of Tri Hita Karana in maintaining the harmonious relationship with fellow human beings by the UP3HP Jempiring Group Badung is also implemented through monthly activities. Monthly activities conducted by the group is an activity that is held as a routine meeting that is to carry out installment payments in groups. Social relationships with the community are also done when group members are in the market, as well as when conducting prayers at temples, transacting at Banks, in LPDs, and in cooperatives as well as in social activities elsewhere. These are all forms of implementation of human harmonious relationships with fellow human beings.

\section{The harmonious relationship between man and the environment (Palemahan)}

Palemahan is derived from word lemah which means land, yard or residential area or residence [36]. Generally speaking, in the THK philosophy, palemahan is a dimension related to the physical aspects of the environment around us or the company. In Bali, palemahan is related to corporate and building layout that should be adjusted to the religious beliefs and culture where the company is located. Humans 
alive on earth need serenity, coolness, tranquility, and happiness of birth and mind. In an effort to achieve that goal man can not live without bhuwana Agung (universe). Humans live in nature and from natural products. This is what underlies the harmonious relationship between man and the universe. In order to maintain the balance and harmony of nature, Hindu people perform tumpek uye (tumpek kandang), which aims to preserve the life of animals and carry out tumpek wariga (tumpek bubuh) to preserve the plants. The direction and objective of Tri Hhita Karana are to reach mokrastham jagad hita ya ca iti dharma, namely to achieve the happiness of the birth and soul so that with harmony then the happiness is the goal of the end of Hinduism that is the unity of atman with paramatman.

Religious ceremonies/rituals in an effort to maintain a harmonious relationship with nature and the environment are through the ceremony Butha Yadnya. Bhuta Yadnya ceremony is a sincere sacred offering to the elements of nature (nurturing natural welfare). This ceremony is more directed to the purpose of Nyomia Bhuta Kala or various negative forces that are considered to interfere with human life. Bhuta Yadnya essentially aims to realize Bhuta Kala become Bhuta Hita. Bhuta Hita means to prosper and preserve the natural environment (Sarwaprani). Bhuta Yadnya ceremony is more likely to nyomia or reconcile/neutralize the negative forces in order not to interfere with the life of mankind and even expected to help mankind.

Bhuta Yadnya ceremonial forms include Segehan, Caru to Tawur. Humans alive on earth need serenity, coolness, peace and pleasure and inwardness. Humans live in nature and from natural products. This is what underlies the harmonious relationship between man and the universe. To maintain balance with nature, Hindu people carry out tumpek uye (tumpek kandang), which aims to preserve the life of the animals, and implement tumpek warige (tumpek bubuh) to preserve the plants [37].

Implementation of human relations with the natural environment that is realized in Bhuta Yadnya by UP3HP Jempiring Group Badung regency that is the implementation of mecaru ceremony at village intersection, mebanten in the motherland, mecaru in each housing. Harmonious relationship to maintain balance with nature and its environment by arranging offerings in natar pelinggih, home natar. This offering is a form of gratitude to Mother Nature as a guardian of nature and this environment. Maintain and keep the sugih leaf, shoots, and some pets as well as the implementation of the harmonious relationship with the environment. Thus, the group of business actors can be said in the business activities always maintain a harmonious relationship with the natural environment as a form of implementation Tri Hita Karana.

In addition, the concept of palemahan is also applied by accounting for the preservation of the limited nature of the environment within a particular area. This responsibility is assumed by the community in the territory. Palemahan at the regional level covers the province of Bali. At the village level, the adat includes "asengken" bale Agung. At the family, level includes a yard of a housing. A real example of the application of this concept is the awig-awig (rule) in a village that forbids illegal logging [35]. In line with research [38] "The Samurai and Bushidian Teachings in a Character Education Perspective". Bushido cannot be separated from the attitude of Samurai in running his belief. Generally, the Samurai follow and practice Zen Buddhist beliefs, based on the deepening, an attitude arises to seek harmony with the universe, especially with the natural environment. This is in line with one of the implementations of Tri Hita Karana is a harmonious relationship that is always maintained to the natural environment.

Relationship of the financial performance of UP3HP Jempiring Group of Badung regency with the 
local wisdom of Tri Hita Karana based on theory perspective of reality construction socially known from member's attitude and decision influenced by internal and external factors whose volume must be different. There is a social relationship in the community hereditary is believed by the UP3HP Jempiring Group Badung regency such as religious ritual activities, as well as the sale of snacks for religious ceremonies. In every action taken by members of UP3HP Jempiring Group of Badung regency based on communication and interaction between individuals. Decisions can be agreed consciously or unconsciously by each individual, which is then passed down from generation to generation, digested and perfected when the process of social interaction takes place. As Berger and Luckman argue that reality in everyday life has given memory, awareness, knowledge that guides every human action that is deemed natural. This indication explains that the meaning contained in everyday life in the UP3HP Jempiring Group of Badung regency will not exist without interaction and communication with others, either with the community or with fellow group members.

The reality in the view of social construction is very concerned with the continuous dialogical process that occurs between one individual with another individual, especially on the meaning of each individual formed about the business group that existed all this time. Based on existing social reality, Berger and Luckman consider that the most important element in social construction is society, in which there are rules or norms, be it customary, religious, moral and other norms. The UP3HP Jempiring group of Badung regency is formed in a social structure, in which there are regular meetings at the end of each month, there are rules that are not written but agreed by the members of the group, there is a religion that is used as the basis of the foothold in the life of the group, and in the life of the community. The social structure is an established pattern followed by members of UP3HP Jempiring Group Badung regency. The consequences of such social structure may be seen as confronting the individual as an objective reality in which the individual members of the group must adapt to the rules, norms created and agreed upon by all members of the group as guidelines that serve to regulate the members' behavior in achieving better goals.

The daily life of members of UP3HP Jempiring Group of Badung Regency displays objective reality interpreted and interpreted by each individual either objectively or subjectively. The results of social interaction that occurred in the UP3HP Jempiring Group of Badung Regency formed a mutual knowledge, which was done repeatedly, which changed into a habit that has been going on and gave rise to a tradition, which will then be passed on to the next generation to be preserved.

This research, if related to Bushido research that teaches about loyalty, ethics, manners, manners, discipline, sacrifice, hard work, is in accordance with this research which relates between financial performance of UP3HP Jempiring Badung with Tri Hita Karana local wisdom, namely the existence of elements of hard work, discipline in work and accountable for the assistance provided by Badung regency, and the willingness to sacrifice in the form of yadnya. Based on the teachings of Confucianism that is the doctrine of obedience and loyalty, respect for status and hierarchy, emphasis on selfdevelopment and education, and attention to social harmony in line with research on UP3HP Jempiring Group Badung. The research that connects performance with the local wisdom of Tri Hita Karana is that which emphasizes on a harmonious relationship which must be maintained to God as a creator of all creatures, to human beings and to the natural environment in which the group is active.

South Korea's economic progress is a culture of hard work and a high work ethic and love of domestic products make the products produced consumed by the domestic market is also in line with 
research conducted on UP3HP Jempiring Group Badung. Products produced and sold by group members are local products especially used by local people in Bali. In line with the results of a study of a group of people in Germany who pointed out that, modern business figures, high-skilled employees, professionals, both technical and commercial, are Protestants proven to give the spirit to work hard, innovations as an effort to achieve life's prosperity and spiritual well-being. Other studies linking economics with local wisdom, ie moral or ethical jiritsu jiei (independent), shoujiki (honest), kimben (diligent), kesaku (frugal), jizen (charity), koueki (for the public interest). Shoujiki and jizen can be regarded as aspects of humanity, while the ethics of kenyaku is an aspect of rationality [39], in line also with research conducted on UP3HP Jempiring Group of Badung regency that relate between financial performance with local wisdom Tri Hita Karana.

Strengthening the financial performance relationship of UP3HP Jempiring Badung with Tri Hita Karana local wisdom can also be done through group discussion (Focus Group Discussion/FGD). FGD was held on October 3, 2016, with members of UP3HP Jempiring Group of Badung Regency and some community leaders who deliberately chosen to represent in giving income about performance relationship of UP3HP Jempiring Group of Badung regency with local wisdom Tri Hita Karana. Based on FGD results it can be concluded that the performance achieved during January to June 2015 has a very close relationship with local wisdom Tri Hita Karana, even members who attended the FGB on October 3, 2016, stated that $100 \%$ have a relationship very closely.

\section{Conclusion}

Based on the results of the analysis and discussion can be concluded that local wisdom Tri Hita Karana very strong in influencing the financial performance of UP3HP Jempiring Group in Badung regency. This influence can be seen from the implementation of Tri Hita Karana's philosophy in the daily life of the members of the group that is their obedience and belief in God (Ida Sang Hyang Widi Wasa) (Parhyangan), shown by the group members by obediently performing their religious ceremonies (Panca Yadnya) as well as incidentally, in accordance with the circumstances of religious ceremonies in Bali.

Obedience and honesty in returning its debts either debt on savings and loan group (direct community aid funds) from Badung regency government, debt to local village Credit Institution (LPD), debt repayment to Bank BRI, Bank PDB (operating in local village), as well as on the co-operative debts in the working area of the group (Pawongan).

The group also remained obedient in preserving the suji tree plant which is always used for dyes in making various processed agricultural products (various snacks for religious ceremonies), as well as the loyalty of some members in raising birds and dogs (Palemahan).

\section{Acknowledgement}

Our deep and sincere gratitude is given to God for giving us health and an opportunity to finish this writing. Thank you very much to our colleagues who have helped in the research and completed this writing.

\section{References}

[1] Malta (2014). Faktor-faktor yang Berhubungan dengan Tingkat Kinerja Petani Jagung Di Lahan Gambut: Kasus Petani Jagung di Lahan Gambut di Desa Limbung - Kabupaten Pontianak. Banda Aceh: Universitas Terbuka, UPBJJ-UT Banda Aceh. 
[2] Mukson, T., Ekowati, Handayani, M. \& Harjanti, D. W. (2009). Faktor-faktor yang Mempengaruhi Kinerja Usaha Ternak Sapi Perah Rakyat di Kecamatan Getasan Kabupaten Semarang. Semarang: Seminar Nasional Kebangkitan Peternakan Semarang 20 Mei 2009. Fakultas Peternakan Universitas Diponegoro.

[3] Adji, P. S. (2015). Pengaruh Budaya Organisasi dan Komunikasi Terhadap Kinerja (Studi Pada Kelompok Tani Sri Mulyo Malang). (serial online), Oktober 2014. http://download.portalgaruda.org/ article. phparticle.

[4] Atmaja, Bawa. Dosen Metodelogi Penelitian. Singaraja: Undiksa.

[5] Astiti, T. I. P., Windia W., Sudantra I K., Marhaendra W. Ari A.A I. (2011). Implementasi Ajaran Tri Hita Karana Dalam Awig-Awig. The Excellence Research. Denpasar: Fakultas Hukum, Universitas Udayana.

[6] Anonim. (2012). Aspek-Aspek Umum Kajian Sosiologi Agama http://mukzizat islam. blogspot.co.id/ 2012/12/aspek-aspek-umum-kajian-sosiologi-agama.

[7] Munawar \& Said, A. (2003). Fikih Hubungan antar Agma. Jakarta: Ciputat Press.

[8] Wagiran (2012). Pengembangan Karakter Berbasis Kearifan Lokal Hamemayu Hayuning Bawana (Identifikasi Nilai-nilai Karakter Berbasis Budaya). Yogyakarta: FT Universitas Negeri Yogyakarta.

[9] Wisnumurti (2014). (serial online) diakses 29 Juni 2014. http///C:/Users/user/Downloads/ Kearifan-Lokal.html.

[10] Purnami (2011). Hidup Harmoni Dalam Bingkai Tri Hita Karana. (serial online) diakses 26 April 2014. http://teologihindu. blogspot.com /2011/ 03/ hidup-harmoni-dalam-bingkai-tri-hita.html.

[11] Irham (2011). Analisis Laporan Keuangan. Bandung: Penerbit ALFABETA.

[12] Darsono \& Ashari (2005). Pedoman Praktis Memahami Laporan Keuangan. Yogyakarta: Penerbit Andi.

[13] Husnan, S. (2007). Manajemen Keuangan Asuransi, Teori dan Terapan. Jilid Pertama. Jakarta: Rineka Cipta.

[14] Rivai, V., Ahmad F. M., Jauvani, S., Silviana, M. (2011). Perpormance Appraisal. Jakarta: Penerbit PT RajaGarfindo Persada.

[15] Lina, L., Sudjana, N., \& Endang W.N.P. (2013). Analisis Kinerja Keuangan Perusahaan dengan Menggunakan Metode Economic Value Added (Eva) dan Metode Market Value Added (MVA) (Studi pada PT Japfa Comfeed Indonesia Tbk. dan PT Charoen Pokphand Indonesia Tbk. di BEI Periode 2009-2011). Malang: Fakultas IlmuAdministrasi Universitas Brawijaya.

[16] Harjito (2008). Dasar-dasar Manajemen Keuangan. Edisi keempat. Malang: Universitas Muhammadiyah Malang.

[17] Kasmir (2011). Analisa Laporan Keuangan. Jakarta: Rajawali Pers.

[18] Wiyasha (2007). Akuntansi Manajemen untuk Hotel dan Restoran. Yogyakarta: Penerbit Andi.

[19] Manuaba, I. B. (2010). Memahami Teori Konstruksi Sosial. Jurnal Masyarakat Kebudayaan Dan Politik Volume 21. Nomor 3:221-230. Surabaya: Fakultas Ilmu Budaya. Universitas Airlangga.

[20] Berger, P. \& Luckmann. T. (1990). Tafsir Sosial Atas Kenyataan: Risalah Tentang Sosiologi Pengetahuan (diterjemahkan dari buku asli the Social Construction of Reality oleh Hasan Basari). Jakarta: LP3ES.

[21] Bertens, K. (1999). Sejarah Filsafat Yunani. Yogyakarta: Kanisius.

[22] Basrowi, \& Sukidin (2002). Metode Penelitian Kualitatif Perspektif Mikro. Surabaya: Insan Cendekian.

[23] Subiakto, H. (2012). anatomi-teori (serial online) diakses 26 Desember $2014 . \quad$ http:// henrysubiakto.blogspot.com/2012/05/anatomi-teori-pemikiran-peter.

[24] Fahri (2007). (serial online). di akses 23 Oktober 2014. http://fahri99. wordpress.com/2007/06/26/ realitassebagai-hasil-konstruksi-2.

[25] Demartoto, A. (2013). Teori Konstruksi Sosial Peter L. Berger dan Thomas Luckman. Jakarta: LP3ES.

[26] Focus Group Discussion (FGD). Diakses dari: http://www.enolsatoe.org/ content/view/15/33/. Sitasi 23 Maret 2009.

[27] Moleong, L. J. (2007). Metode Penelitian Kualitatif. Bandung: PT. Remaja Rosdakarya.

[28] Hendropuspito (1983). Sosiologi Agama.Yogyakarta: Kanisius.

[29] Suryathi, N.W., \& Resiani, N.M.D (2015). Kinerja Kelompok Pelaku Usaha “Jempiring” Dari Perspektif Manajemen Keuangan Di Desa Blahkiuh - Abiansemal - Badung. Buletin Teknologi dan Informasi Pertanian, Vol.13 No. 39 Agustus 2015.

[30] Gorda (1995). Membudayakan Kerja Berdasarkan Dharma. Singaraja: Pusat Kajian Hindu. Budaya dan Perilaku Organisasi. Sekolah Tinggi Ilmu Ekonomi Satya Dharma.

[31] Riana, G. (2011). Dampak Penerapan Kultur Lokal Tri Hita Karana terhadap Orientasi Kewirausahaan dan Orientasi Pasar. Jurnal Teknik Indonestri. Vol. 13 No. 1. ISSN 1411-2485 print/ISSN 2087-7439 
The Effect of Tri Hita Karana Local Wisdom on Financial Performance of UP3HP Jempiring Group in Regency Badung

online.

[32] Donder, I.K. (2017). Unsur-unsur Sain dan Teknologi dalam Ritual Hindu. Surabaya: Wordd Hindu Parisad dan Paramita.

[33] Windia, W. \& Dewi, R. (2011). Analisis Bisnis yang Berlandaskan Tri Hita Karana. Denpasar: Universitas Udayana Press.

[34] Yayasan, Bali Galang. (2015). Tafsir Agama Hindu- Tri Hita Karana dalam Agama Hindu. http:// www.babadbali.com/canangsari/trihitakarana.htm. diakses, Oktober 2015.

[35] Agus (2011). Tri Hita Karana Dalam Pendidikan di Bali. (serial online), Oktober 2014. http:/pandeagus. blogspot.com 2011/12/tri-hita-karana-dalam-pendidikan-di.html.

[36] Anonim. (2015a). (serial online). http://eprints. ung. ac.id/4653/6/2012-1-62201-241408079-bab213082012112859. Diakses, Desember 2015.

[37] Tarna, W. (2014). Implementasi Tri Hita Karana. Jakarta. Sekolah Tinggi Agama Hindu Dharma Nusantara.

[38] Suharman (2002). Sejarah Jepang (Awal sampai Feodalisme). Salatiga Jawa Tengah: Widya Sari Press.

[39] Wibawarta (2006). Bushido dalam Masyarakat Jepang Modern. Wacana Vol. 8 No. 1, April 2006. 